endosperm nodule. The really interesting feature in the embryology of Isomeris arborea is the formation of a massive suspensor haustorium. This consists of densely cytoplasmic multinucleate cells which were misinterpreted by Billings as endosperm nodules.

Thanks are due to the Indian Council of Agricultural Research for a research grant in connexion with a scheme on "Chemical Stimulation of the Ovule", and to Mr. S. C. Maheshwari for some useful suggestions in the interpretation of the nature of the endosperm and embryo.

P. MaHeshwari

Botany Department,

R. C. SACHaR

University of Delhi,

Delhi 8 , India. July 27.

1 Billings, F. II., New Phytol., 36, 301 (1937).

${ }^{2}$ Gustafsson, A., Lunds Univ. Arsskr. N.F. Avd. II, 43, 71 (1947).

s Maheshwari, P., "An Introduetion to the Embryology of Angiosperms" (New York and London, 1950).

- Tischler, G., “Allgemeine Pflanzenkaryologie”, Band 2 (Bornträger, Berlin, 1942-43).

'Maheshwari, P., and Khan, R., Phytomorph., 3, 446 (1953).

- Maheshwari, P., and Sachar, R. C., Curr. Sci., 23, 61 (1954).

\section{Relationships between the Flying Fox (Genus Pteropus) and Arthropod-borne Fevers of North Queensland}

Dorivg field investigations by one of us (L. C. R.) there was observed a fairly close relation in season and place with areas of the city of Townsville, North Queensland, Australia, in which an extensive epidemic of dengue fever occurred during the months of December 1953 to March 1954.

The history of past epidemics in Queonsland, so far as can be traced, and also observations made by two of us (L. C. R. and J. L. O'C., unpublished) during the course of the 1953-54 epidemic suggested that members of the flying fox genus (Pteropus) might well serve as a reservoir from which the virus could be conveyed to regions closely in association with dwelling-places-because of the habit of these animals of swarming, just after nightfall, from their camps, usually in mangrove swamps, to fruit trees surrounding dwelling places, where they would thus come in close proximity with the known vectors in Townsville (Aedes (Stegomyia) aegypti Linn.).

In investigating this hypothesis a collection was made of various species of Pteropus in and around the Townsville area in the months of October-November 1954 -about two months prior to the usual time

\begin{tabular}{|c|c|c|c|}
\hline Serial No. & Species & Deaths in mice* & $\begin{array}{l}\text { Presence of } \\
\text { antibody }\end{array}$ \\
\hline $\begin{array}{r}F F \text { No. } \\
2 \\
2 \\
3 \\
4 \\
5 \\
6 \\
7 \\
8 \\
9 \\
10 \\
11 \\
12 \\
13 \\
14 \\
15 \\
16 \\
17\end{array}$ & $\begin{array}{c}\text { gouldi } \\
\text { ssapulatus } \\
\text {," } \\
\text { ", } \\
\text { gould̈i } \\
\text { scapulatus } \\
\text { ", } \\
\text { gould"i } \\
\text { ", } \\
\text { ", }\end{array}$ & $\begin{array}{l}0 / 6 \\
5 / 6 \\
5 / 6 \\
2 / 6 \\
3 / 6 \\
4 / 6 \\
3 / 6 \\
4 / 6 \\
6 / 6 \\
3 / 6 \\
0 / 6 \\
6 / 6 \\
5 / 6 \\
0 / 6 \\
0 / 6 \\
8 / 6 \\
1 / 6\end{array}$ & $\begin{array}{l}\text { positive } \\
\text { negative } \\
\text { incon̈clusive } \\
\text { ", } \\
\text { ", } \\
\text { negätive } \\
\text { inconclusive } \\
\text { negative } \\
\quad, " \\
\text { positive } \\
\text { inconclusive } \\
\text { positive }\end{array}$ \\
\hline
\end{tabular}

* The numerator indicates the number of mice dead at the end of the test; the denominator indisates the number of mice inoculated. of onset of dengue fever. It should be observed that only a few sporadic cases occurred in the city over the period December 1954-November 1955.

Specimens of two species were obtained : sixteen of $P$. gouldi and eighteen of $P$. scapulatus. The brains of these were submitted to histological examination, and heart blood to serological test for protective antibodies against the virus of dengue fever Type I. Mice were inoculated with a mixture of equal volumes of inactivated undiluted serum and virus suspension containing 100 mouse $L D$ 50. Mixtures were incubated for two hours at $37^{\circ} \mathrm{C}$. prior to injection into six mice for each serum specimen.

The results of such protection tests are set out in Table 1.

Those tests in which five or six mice survived are taken as positive evidence of the presence of protective antibodies, those in which 0 or 1 mouse survives are interpreted as evidence of the absence of antibody. Tests in which 2,3 or 4 mice survived are regarded as inconclusive.

Although the challenge virus used was dengue Type I (the Hawaiian strain isolated by Sabin), these results are not interpreted as conclusive of past infection by that virus.

Current work by us indicate that there is a very close serological relationship between the virus of dengue fever (Type I) and of Murray Valley encephalitis.

$$
\begin{aligned}
& \text { J. L. O'CoNNOR } \\
& \text { L. C. ROWAN }
\end{aligned}
$$

Commonwealth Serum Laboratories, Melbourne.

\section{J. J. LawRENCE}

School of Public Health and Tropical Medicine, University of Sydney, New South Wales.

\section{A Variable Dosage Sprayer for Agricultural Experiments}

THE present method for testing in the field the toxicity and selectivity of herbicides or other spray chemicals necessitates spraying a number of separate plots with different dosages. Valuable time is wasted in making up solutions and emptying the spraying machine betwoen operations. The time required is longer the closer the gradations of dosage which it is considered necessary to examine. We have designed a machine which makes it possible with one filling to spray continuously decreasing concentrations, starting from an arbitrary upper limit. A whole spectrum of results is thus made available for examination in far less time than is consumed in getting less complete results by the established method.

The dilution principle used is to pump liquid to the spray nozzles from an intermediate vessel which is otherwise closed except for a lead tube from a water-supply vessel, is equipped with an efficient agitator and is initially completely filled. As spray liquid is withdrawn it is replaced by water and the concentration falls in an exponential manner. A coarsely porous plug in the entrance tube of the mixing vessel prevents adventitious dilution. The nozzles are carefully selected to have equal output at a given pressure, and are fed by separate narrow polythene tubes of equal length from a common manifold as close as possible to the pump, so that the same concentration reaches all nozzles simultaneously. 